\title{
Mortality in Glasgow and Edinburgh: a paradigm of inequality in health
}

\author{
Graham C M Watt, Russell Ecob
}

\begin{abstract}
Study objective-The aim was to describe, predict, and interpret mortality in Glasgow and Edinburgh.

Design-The study was an analysis of all cause and cause specific mortality data for quinquennia based on census years between 1931 and 1981, linking age and sex specific mortality rates by year of birth, for people dying between the ages of 25 and 74 years.

Setting-Glasgow and Edinburgh, Scotland.

Main results-Age and sex specific mortality rates declined steadily in Edinburgh and Glasgow during the period 1931-1981, with rates always being lower in Edinburgh than in Glasgow. Since $1961 \mathrm{log}$ mortality rates have tended to rise linearly with age in both cities. In 1979-83, the population of Glasgow reached a given all cause mortality rate 3.9 years earlier in men and 3.6 years earlier in women than did the population of Edinburgh. These differences have increased, and are predicted to increase further, especially in men.

Conclusions-The current $40 \%$ cross sectional difference in mortality rates between the cities is largely determined by levels of mortality in early adulthood which provide a baseline for the subsequent rise in log mortality. Disease specific epidemiology provides a limited view of inequalities in health, and a partial basis for health promotion. Campaigns to alter disease risk profiles in adults should be complemented by measures operating earlier in life to reduce susceptibility to risk. Maternal and child health require greater priority in public health policy, particularly in areas of socioeconomic disadvantage.
\end{abstract}

f Epidemiol Community Health 1992; 46: 498-505

Department of Public Health, University of Glasgow, 2 Lilybank Gardens, Glasgow G12 8RZ, United Kingdom G C M Watt MRC Medical Sociology Unit, University of Glasgow, Glasgow, United Kingdom R Ecob

Correspondence to: Dr Watt
The setting of national health targets implies an understanding of the factors which cause disease and the measures required for prevention. Current policies emphasise individual behaviour as the cause of premature deaths and the target for health promotion campaigns, and assume that by following such policies, mortality rates can be reduced substantially within a decade. Both Scottish and English targets aim to reduce coronary heart disease mortality rates under 65 years of age by $30 \%$ by the year $2000 .^{12}$ To achieve such targets in people aged 55-64 years will require major changes in behaviour and in risk status in people currently aged 45-54. As no controlled intervention study has shown such effects, it is likely that success or failure in achieving the targets will be determined to a large extent by underlying trends in mortality rates. ${ }^{3}$

In order to assess the prospect of achieving national targets, we have compared trends in all cause and cause specific mortality rates in Glasgow and Edinburgh, two cities with a combined population of 1.2 million people, and situated about 40 miles apart in the central belt of Scotland. In 1979-83, death rates from all causes in people aged $25-64$ years were $40 \%$ higher in Glasgow than in Edinburgh. ${ }^{4}$

\section{Methods}

Numerators consisted of all deaths in 10 year age groups for men and women aged 25-74 years in the cities of Glasgow and Edinburgh, occurring in five year periods centred on each census year between 1931 and $1981 .^{4}$

Denominators for these groups were based on census reports from 1931 to $1981 .^{5}$ A mid-census estimate based on the average of figures for 1931 and 1951 provided denominators for 1941, when a census did not take place.

For further analyses, deaths were divided into four broad subgroups comprising deaths in people aged 25-64 years from stroke (ICD 430-8), all heart disease (ICD 390-429), all malignant cancers (ICD 140-208), and other causes, using appropriate diagnostic categories for periods prior to the ninth revision of the International classification of diseases.

Mortality rates were expressed as logarithms to the base 10 . Log-linear age-cohort models, ${ }^{67}$ with a Poisson error structure, ${ }^{89}$ were fitted to the data using the GLIM statistical modelling package. ${ }^{10}$

A feature of statistical models including data for the period 1931-1981 was an interaction between age and cohort (ie, the increase in mortality with age varied by cohort), which was explained by the higher mortality rates at younger ages in earlier cohorts. Accordingly, models were fitted to death rates for quinquennia based on 1961, 1971, and 1981. The rates were based on 106920 deaths in Glasgow and 46020 deaths in Edinburgh.

Seperate models were fitted for men and women. For women the model included interactions between city and cohort only, age being modelled as a variable; for men the model included interactions between city and cohort and between city and age, age being modelled as a factor. For both sexes, an adequate fit to the data was obtained without including an interaction between age and cohort (for men, $\chi_{8}^{2}=10 \cdot 70$, $\mathrm{p}<0.05$; for women, $\chi_{15}^{2}=10.37, \mathrm{p}<0.05$ ).

When there are no interactions between age and cohort, standardised mortality rates may be cal- 
culated for cohorts within cities. ${ }^{11}$ The model may also be used to estimate the sex and city specific increases in age, for any cohort, during which mortality rates double (the doubling times) and to predict mortality rates in 1989-93 in Edinburgh and Glasgow.

Data from the two cities were also modelled simultaneously and the differences in mortality rates between the cities expressed in terms of the difference between the ages at which the two populations experience the same mortality rates. This was achieved by expressing the differences between estimated age and sex specific log mortality rates in Glasgow and Edinburgh as a proportion of the total range of estimated log mortality rates within the 40 year age span of the relevant Edinburgh cohort.

A sensitivity analysis was carried out in order to assess the effect of migration and boundary change. For this purpose, the estimated net outmigrants were reintroduced, with an assumed all cause mortality rate which was $20 \%$ less than that of people who had stayed in each city. This was considered a conservative estimate and was set to be lower than the mortality rates of regional migrants in the OPCS longitudinal study. ${ }^{12}$

Estimates of net migration were obtained by calculating the number of expected deaths in an age-sex group during a 10 year period, and subtracting this from the observed change in the size of the group between census years. For example, the expected number of deaths over 10 years in men aged 45-54 years in 1951 was

Figure 1 Trends in all cause mortality rates in men and women in Glasgow and Edinburgh between 5 year periods, centred on census years.

Figure 2 Trends in all cause mortality rates in Glasgow and Edinburgh linking age and sex specific rates by year of birth.
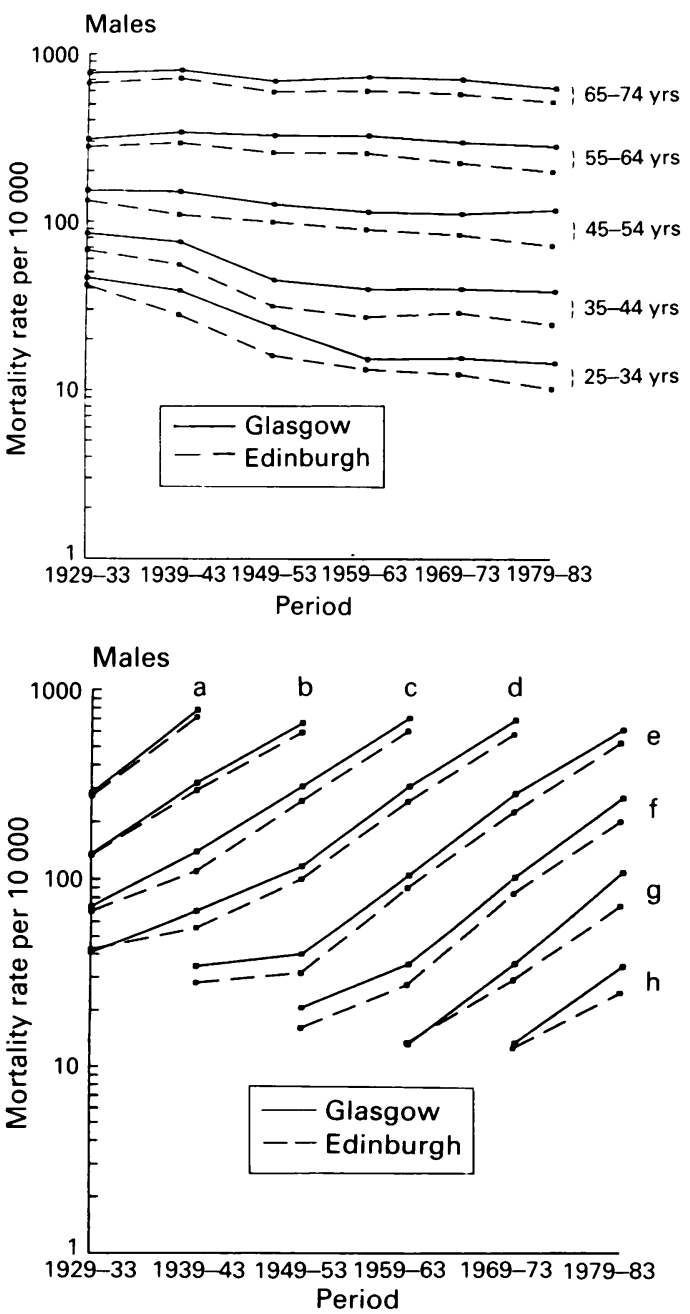

estimated by applying an average mortality rate based on mortality rates for men aged 45-54 in 1951 and 55-64 in 1961.

The only boundary change of significance between 1931 and 1981 occurred in 1974 when the populations of Edinburgh and Glasgow increased by $5 \%$ and $9 \%$ respectively as a result of local government reorganisation. Our method of estimating net migration underestimates the total amount of out-migration during 1971-1981, because of the substitution of out-migrants by new population due to boudary change. The estimates of out-migration (table VI) and the sensitivity analysis include these "hidden" migrants. It is impossible to assess precisely the effect on mortality rates of the new populations included in 1974 because of small numbers, random variation, background trends, and uncertainty concerning denominators. We assumed a "worst case" for the sensitivity analysis, therefore, and in excluding the new populations from our re-estimation of mortality rates for 1979-83 and 1989-93, we assumed that their relative mortality rates compared to rates observed in Glasgow and Edinburgh in 1969-73 were $10 \%$ higher and $10 \%$ lower respectively.

\section{Results}

DESCRIPTIVE DATA

Cross sectional comparisons of all cause mortality show that mortality rates for men declined throughout the period 1931-1981, with rates in
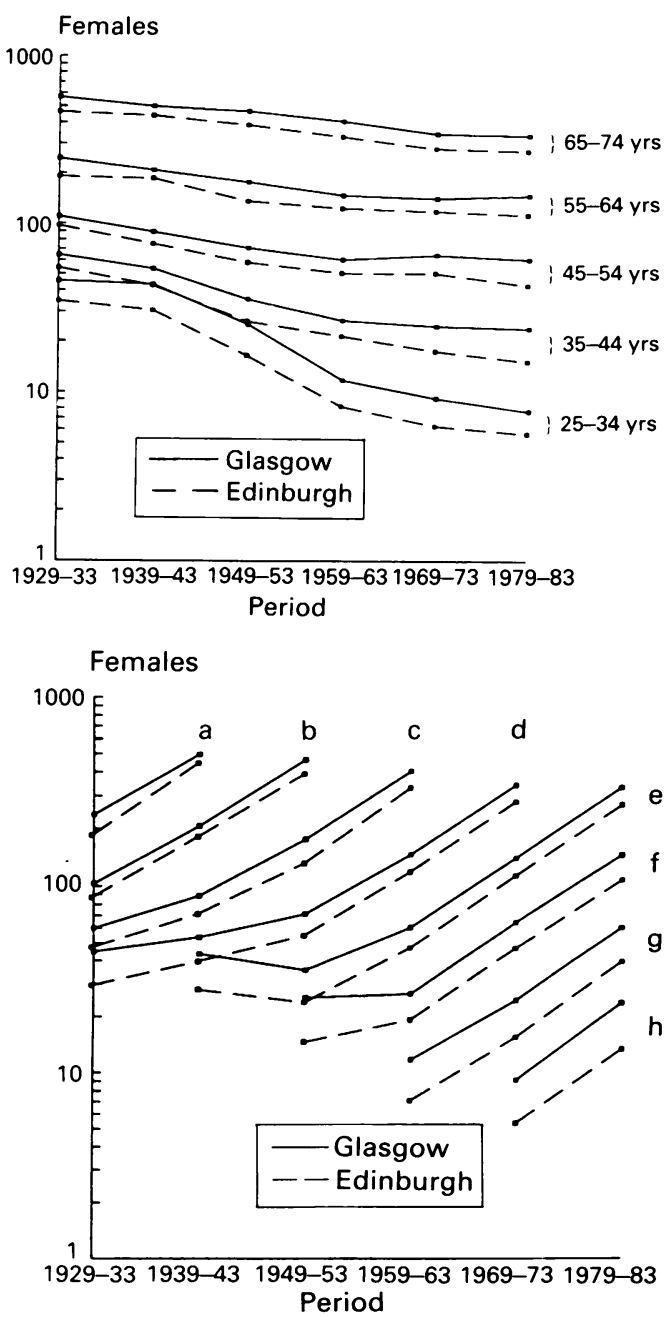

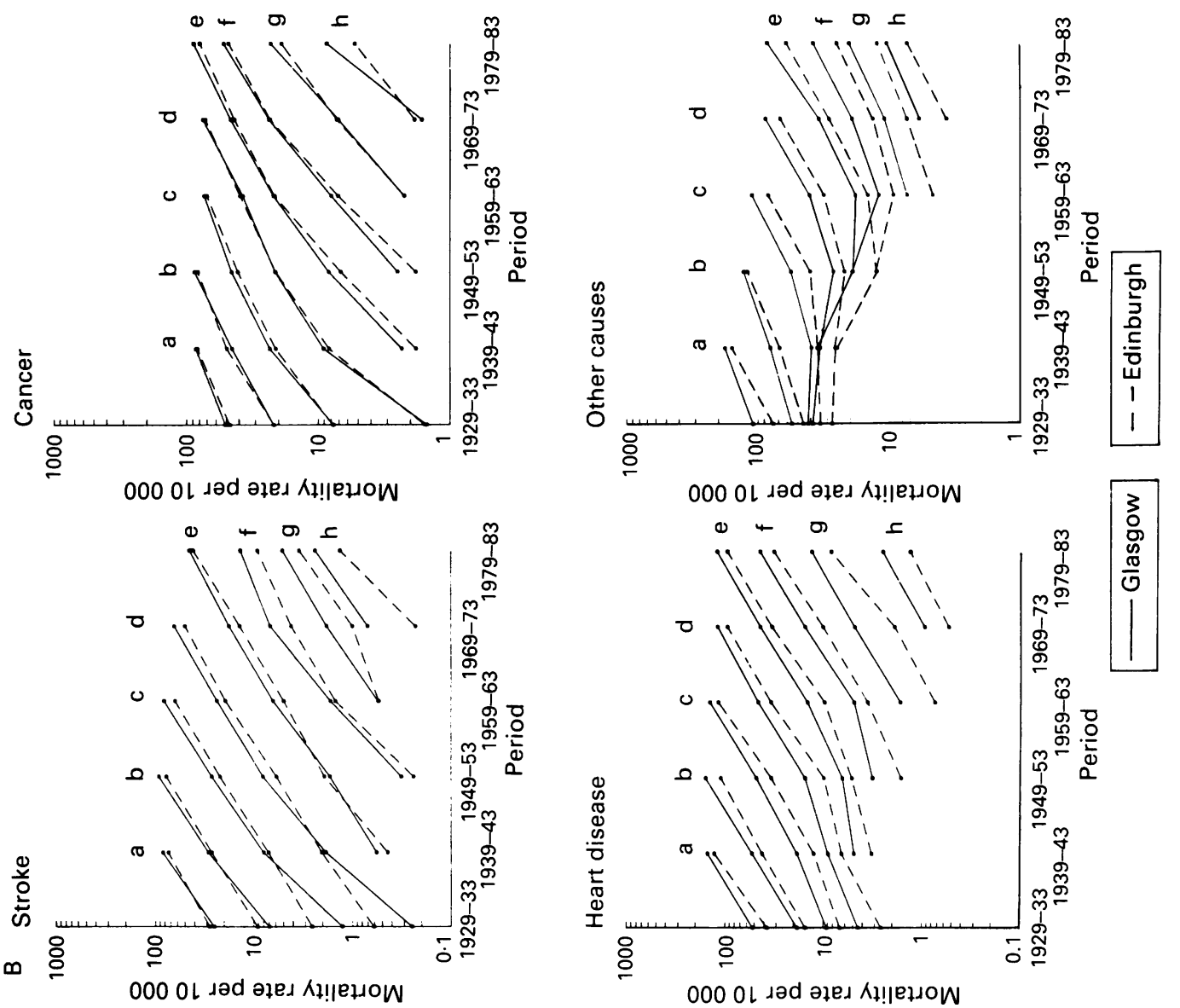

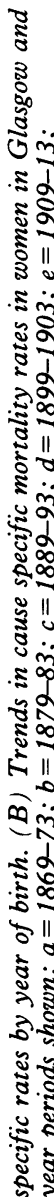
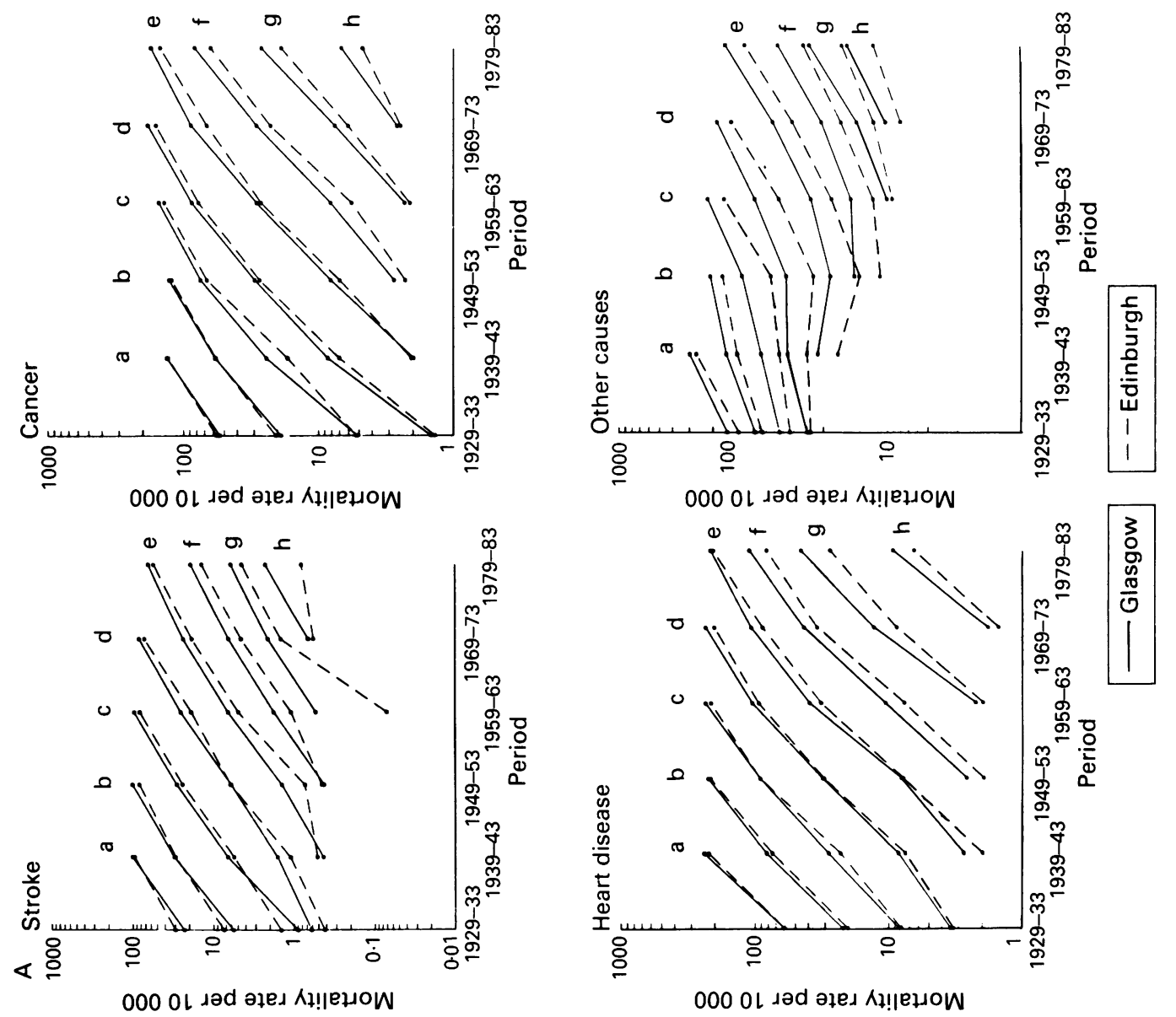

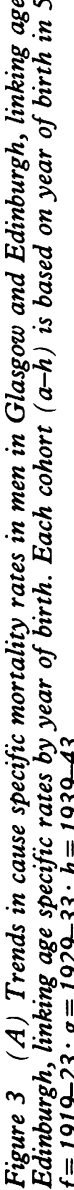


Glasgow always being higher than rates in Edinburgh (fig 1). The same pattern applies to women, mortality rates for women being consistently lower than for men. In almost every age and sex category, there is a lag of 20-30 years between the most recent mortality rates in Glasgow and the period when similar rates were observed in Edinburgh.

Linkage of mortality rates by year of birth, to create synthetic cohorts, shows that as middle age approaches there is an almost linear tendency for all cause $\log$ mortality rates to increase with age (fig 2). The tendency appears at an earlier age in later cohorts because of the declining effect of premature death from infectious diseases. This can be seen when the data are displayed separately for deaths from specific causes (fig 3). Deaths from stroke, all heart disease, and all malignant cancers each show linear trends within cohort by age. Deaths from other causes, including infectious diseases, show higher rates in earlier cohorts at younger ages.

Table I Mortality rates for Glasgow expressed as a percentage of Edinburgh rates, by age and sex, 25-64 years, $1979-83$.

\begin{tabular}{|c|c|c|c|c|c|c|}
\hline $\begin{array}{l}\text { Age } \\
\text { group (years) }\end{array}$ & $\begin{array}{l}\text { All } \\
\text { cause }\end{array}$ & $\begin{array}{l}\text { Cancer } \\
\text { (ICD } 140\end{array}$ & $-208)$ & $\begin{array}{l}\text { Stroke } \\
\text { (ICD 430-438) }\end{array}$ & $\begin{array}{l}\text { Heart } \\
\text { (ICD 390-429) }\end{array}$ & $\begin{array}{l}\text { Other } \\
\text { disease }\end{array}$ \\
\hline $\begin{array}{l}25-34 \\
35-44 \\
45-54 \\
55-64\end{array}$ & $\begin{array}{l}140.4 \\
154.6 \\
160.0 \\
137.8\end{array}$ & $\begin{array}{l}117 \cdot 7^{\text {NS }} \\
143 \cdot 4^{\star} \\
140 \cdot 9^{-1} \\
131 \cdot 1\end{array}$ & Males & $\begin{array}{l}165 \cdot 4^{\mathrm{NS}} \\
277 \cdot 6 \mathrm{t} \\
137 \cdot 3^{\mathrm{NS}} \\
136 \cdot 4 \dagger\end{array}$ & $\begin{array}{l}114.5^{\mathrm{NS}} \\
143 \cdot 3 \dagger \\
165 \cdot 0 \\
134.3\end{array}$ & $\begin{array}{l}136.8 \\
153.8 \\
157.4 \\
135.8\end{array}$ \\
\hline $25-64$ & 144.5 & $133 \cdot 6$ & & 143.0 & $142 \cdot 0$ & $142 \cdot 1$ \\
\hline $\begin{array}{l}25-34 \\
35-44 \\
45-54 \\
55-64\end{array}$ & $\begin{array}{l}136 \cdot 7^{\star} \\
157 \cdot 3 \\
142 \cdot 0 \\
129 \cdot 8\end{array}$ & $\begin{array}{l}126 \cdot 0^{\mathrm{NS}} \\
162 \cdot 9^{120 \cdot 4^{\star}} \\
109 \cdot 1^{\mathrm{NS}}\end{array}$ & Females & $\begin{array}{l}396 \cdot 3^{\star} \\
178 \cdot 4^{\mathrm{N} S} \\
147 \cdot 8^{\star} \\
149 \cdot 0\end{array}$ & $\begin{array}{l}132 \cdot 1^{\text {NS }} \\
190 \cdot 0^{\star} \\
157 \cdot 5 \\
138 \cdot 7\end{array}$ & $\begin{array}{l}140 \cdot 8 \dagger \\
161 \cdot 7 \\
138 \cdot 5 \\
127 \cdot 2\end{array}$ \\
\hline $25-64$ & $135 \cdot 0$ & 115.9 & & $155 \cdot 1$ & 143.7 & 132.5 \\
\hline
\end{tabular}

All comparisons between Glasgow and Edinburgh rates are statistically significant $(p<0.001)$, unless annotated otherwise ${ }^{\star} \mathrm{p}<0.05 ; \mathrm{tp}<0.01$

\section{ANALYTICAL DATA}

In the five year period centred on 1981, the standardised mortality ratio for age groups 25-64 years for Glasgow relative to Edinburgh was 145 for men and 135 for women (table I). Standardised mortality ratios for specific causes were similar for men with the exception of the lower value for all malignant cancers (134), while for women there was some variation in the ratios, which were lowest for all malignant cancers (116) and highest for stroke (155). In the malignant cancer category, mortality ratios were particularly high for lung cancer (158 for men, 141 for women), but rates were also higher in Glasgow for malignant cancers other than lung cancer ( 116 for

Table II Standardised mortality ratios in age range 25-74 years relative to cohort born 10 years previously.

\begin{tabular}{|c|c|c|c|c|c|}
\hline \multirow[b]{2}{*}{$\begin{array}{l}\text { Year of } \\
\text { birth }\end{array}$} & \multirow{2}{*}{$\begin{array}{l}\text { No of age } \\
\text { groups for } \\
\text { comparison }\end{array}$} & \multicolumn{2}{|l|}{ Men } & \multicolumn{2}{|l|}{ Women } \\
\hline & & $\begin{array}{l}\text { Glasgow } \\
(\%)\end{array}$ & $\begin{array}{l}\text { Edinburgh } \\
(\%)\end{array}$ & $\begin{array}{l}\text { Glasgow } \\
(\%)\end{array}$ & $\begin{array}{l}\text { Edinburgh } \\
(\%)\end{array}$ \\
\hline $1897-1906$ & 1 & \multirow{6}{*}{$\begin{array}{l}97 \cdot 6 \\
(92 \cdot 1-103 \cdot 3) \\
90 \cdot 7 \\
(86 \cdot 2-95 \cdot 5) \\
97 \cdot 2 \\
(94 \cdot 7-99 \cdot 9) \\
104 \cdot 9 \\
(100 \cdot 6-109 \cdot 4) \\
96 \cdot 6 \\
(87 \cdot 9-106 \cdot 1) \\
96 \cdot 2 \\
(81 \cdot 1-114 \cdot 0)\end{array}$} & \multirow{6}{*}{$\begin{array}{l}97 \cdot 3 \\
(88 \cdot 7-106 \cdot 8) \\
89 \cdot 6 \\
(82 \cdot 6-97 \cdot 3) \\
89 \cdot 5 \\
(85 \cdot 8-93 \cdot 4) \\
92 \cdot 2 \\
(86 \cdot 0-98 \cdot 9) \\
92 \cdot 7 \\
(78 \cdot 9-108 \cdot 9) \\
82 \cdot 6 \\
(68 \cdot 3-94 \cdot 8)\end{array}$} & \multirow{6}{*}{$\begin{array}{l}84 \cdot 8 \\
(79 \cdot 2-90 \cdot 7) \\
97 \cdot 3 \\
(91 \cdot 5-103 \cdot 5) \\
103 \cdot 6 \\
(100 \cdot 3-107 \cdot 0) \\
99 \cdot 6 \\
(94 \cdot 8-104 \cdot 5) \\
98 \cdot 8 \\
(89 \cdot 0-109 \cdot 7) \\
92 \cdot 6 \\
(81 \cdot 5-116 \cdot 8)\end{array}$} & \multirow{6}{*}{$\begin{array}{l}86 \cdot 1 \\
78 \cdot 3-94 \cdot 7) \\
96 \cdot 7 \\
(88 \cdot 5-105 \cdot 9) \\
97 \cdot 7 \\
(93 \cdot 2-102 \cdot 5) \\
86 \cdot 5 \\
(80 \cdot 1-93 \cdot 4) \\
82 \cdot 0 \\
(69 \cdot 8-96 \cdot 4) \\
87 \cdot 2 \\
(74 \cdot 7-103 \cdot 0)\end{array}$} \\
\hline 1907-1916 & 2 & & & & \\
\hline $1917-1926$ & 3 & & & & \\
\hline 1927-1936 & 3 & & & & \\
\hline 1937-1946 & 2 & & & & \\
\hline 1947-1956 & 1 & & & & \\
\hline
\end{tabular}

$95 \%$ confidence intervals in brackets men, 109 for women). The largest differences in age specific all cause mortality rates occurred in the age groups $35-44$ and $45-54$ years.

Comparing fitted standardised all cause mortality rates for 12 age-sex cohorts at successive quinquennia, using data from 1961 to 1981 , a decline in mortality rate is shown in each cohort compared to the previous one, with the exception of Glasgow men born around 1931 and Glasgow women born around 1921 (table II). The decreases in mortality rates are larger in Edinburgh than in Glasgow for all male cohorts and for five out of the six female cohorts.

For women the log mortality rate doubles for each cohort in each city in 8.2 years; for men the doubling time is 7.5 years in cohorts in Glasgow and 8.0 years in cohorts in Edinburgh.

Compared to age and sex specific rates observed in 1979-83, the models predict that in 1989-93, with other factors being unchanged, mortality rates in men and in older women will tend to remain at a similar level in Glasgow, while a reduction may be expected in both sexes in Edinburgh (table III).

In 1959-1963, Glasgow men and women had mortality rates which were equivalent to rates experienced by men and women in Edinburgh who were 2.4 years and 2.8 years older repectively. In 1979-83, these differences had increased to 3.9 years and 3.6 years. The model predicts that by 1989-93 the differences will increase to $5 \cdot 1$ years for men (an increase of $31 \%$ ) and to 3.9 years for women (an increase of $8 \%$ ).

The differences in estimated mortality rates between the cities vary by sex and age (table IV). For every age group in the range 35-64 years and in all periods under consideration the differences between Glasgow and Edinburgh on the Edinburgh age equivalent scale are larger in men. In the age group 65-74 years, they are larger in women. In both sexes the differences are generally larger in younger age groups. These results reflect the differences between cities by age and cohort for men and by cohort only for women, the terms in the city-cohort interaction showing a systematic tendency to increase as cohorts become more recent.

Comparison of predicted age specific all cause mortality rates for Glasgow and Edinburgh in 1989-93 (table V) also shows larger differences between the cities in younger age groups, suggesting that the average differences in mortality rates between cities will increase in the next few decades.

With the exception of a slight increase in population size in Edinburgh after the second world war, there was a steady loss of population from both cities throughout the period 1931-1981 (table VI). Out-migration was most marked for the youngest age groups for the periods 19611971 and 1971-1981, and was higher in Glasgow than in Edinburgh.

As net out-migration was generally higher in Glasgow, and migrants are assumed to be more healthy than the non-mobile population, we expected that the predicted differences between Glasgow and Edinburgh would reduced after reintroducing migrants. In the sensitivity analysis, which attempted to take account of both out-migration and boundary changes in 1974, the 
Table III Predicted numbers of deaths and estimated age specific all cause mortality rates (per 10 000) for Glasgow and Edinburgh in 1989-93.

\begin{tabular}{|c|c|c|c|c|}
\hline $\begin{array}{l}\text { Age group } \\
\text { (years) }\end{array}$ & $\begin{array}{l}\text { Estimated } \\
1979-83 \\
\text { mortality } \\
\text { rates per } \\
10000\end{array}$ & $\begin{array}{l}\text { Predicted }^{\mathrm{a}} \\
1989-93 \\
\text { mortality } \\
\text { rates }(95 \% \mathrm{CI}) \\
\text { per } 10000\end{array}$ & $\begin{array}{l}\text { Predicted } \\
\text { No of deaths } \\
\text { in } 1989-93\end{array}$ & $\begin{array}{l}\text { Ratio of } \\
\text { mortality rates } \\
1989-93 / 79-83\end{array}$ \\
\hline $\begin{array}{c}\text { Glasgow m } \\
35-44 \\
45-54 \\
55-64 \\
65-74\end{array}$ & $\begin{array}{r}39 \\
115 \\
280 \\
619\end{array}$ & $\begin{array}{c}37(33-43) \\
111(96-128) \\
293(257-335) \\
602(526-688)\end{array}$ & $\begin{array}{r}158 \\
370 \\
994 \\
1598\end{array}$ & $\begin{array}{l}0.96 \\
0.96 \\
1.05 \\
0.97\end{array}$ \\
\hline $\begin{array}{c}\text { Glasgow w } \\
35-44 \\
45-54 \\
55-64 \\
65-74\end{array}$ & $\begin{array}{r}23 \\
61 \\
149 \\
336\end{array}$ & $\begin{array}{c}18(16-21) \\
54(45-64) \\
142(121-168) \\
348(297-409)\end{array}$ & $\begin{array}{r}76 \\
155 \\
571 \\
1309\end{array}$ & $\begin{array}{l}0 \cdot 78 \\
0.89 \\
0.96 \\
1 \cdot 04\end{array}$ \\
\hline $\begin{array}{c}\text { Edinburgh } \\
35-44 \\
45-54 \\
55-64 \\
65-74\end{array}$ & $\begin{array}{r}25 \\
75 \\
203 \\
522\end{array}$ & $\begin{array}{c}21(17-25) \\
69(56-86) \\
187(152-230) \\
467(380-575)\end{array}$ & $\begin{array}{r}64 \\
154 \\
391 \\
784\end{array}$ & $\begin{array}{l}0.83 \\
0.93 \\
0.92 \\
0.90\end{array}$ \\
\hline $\begin{array}{l}\text { Edinburgh } \\
35-44 \\
45-54 \\
55-64 \\
65-74\end{array}$ & $\begin{array}{r}15 \\
43 \\
116 \\
277\end{array}$ & $\begin{array}{cc}13 & (11-16) \\
35 & (28-45) \\
100 & (80-126) \\
271 & (217-339)\end{array}$ & $\begin{array}{r}40 \\
86 \\
242 \\
612\end{array}$ & $\begin{array}{l}0 \cdot 87 \\
0 \cdot 82 \\
0 \cdot 87 \\
0.98\end{array}$ \\
\hline
\end{tabular}

$\mathrm{CI}=$ confidence interval

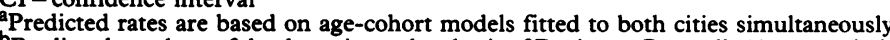

bredicted numbers of deaths estimated on basis of Registrar General's 1989 population estimates

predicted differences for 1989-93, averaged over the 35-74 year age group, were indeed lower by $7 \cdot 1 \%$ for both men and women. Estimates of differences between Glasgow and Edinburgh showed reductions in most age-period-sex combinations. The estimates of the increases in the differences over time (between 1959-63 and 1989-93) were also reduced (by $14.3 \%$ for men and $16.4 \%$ for women). However, the overall pattern described above was unaltered (table IV).

\section{Discussion}

That age specific patterns of mortality in adulthood more or less follow an exponential function of age has been known since the early 19th century. ${ }^{13}$ Studies of the phenomenon have compared mortality rates between countries, ${ }^{14-17}$ and between cohorts within countries. ${ }^{15-17} \mathrm{~A}$ previous Scottish study compared mortality rates in town and country areas. ${ }^{18}$ As far as we know,

Table IV Increased mortality in Glasgow expressed as the differences in years between the chronological ages at which the populations of Glasgow and Edinburgh experience the same mortality rates, with and without adjustment for migration and boundary change.

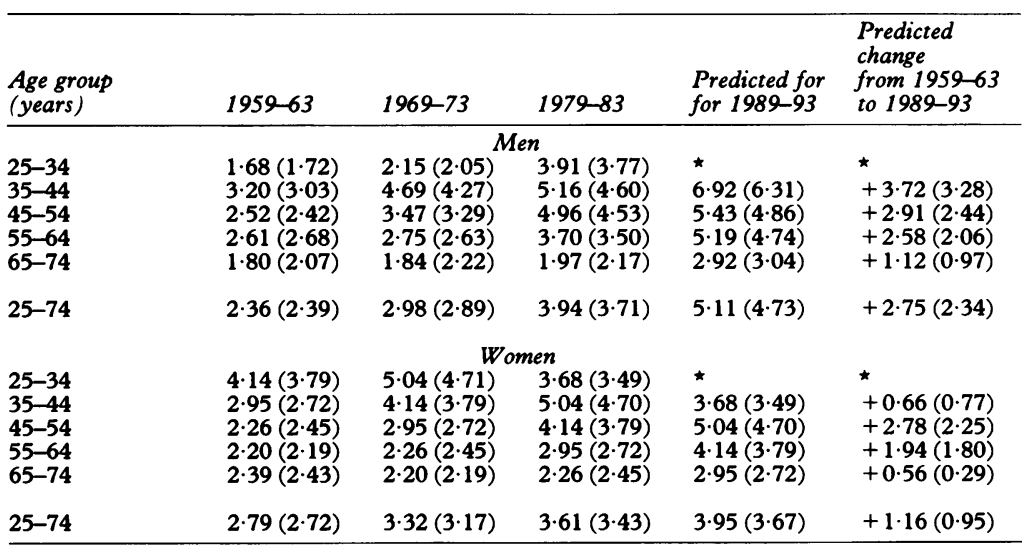

^Cannot be predicted from statistical model.

Figures in brackets include migrants with mortality rates assumed as $80 \%$ of rates of resident population; after 1974, they exclude new population added as a result of boundary change (see text).

Differences in the 25-74 year age group are unweighted averages of differences in age specific groups. ours is the first study to apply this approach to the interpretation of present day inequality in health. ${ }^{19}$

In the cross sectional analysis (fig 1), mortality rates have declined in Glasgow and Edinburgh, but a large difference between the cities has persisted and is now increasing, especially in men (table V). In the "cohort" analysis of all cause mortality rates (figs 2 and 3), the rates at which log mortality rates have increased with age (indicated by the doubling times) show a regular pattern in each city for all male and female cohorts. The doubling times are similar for women in both cities, shorter for men than for women, and shorter for men in Glasgow than for men in Edinburgh. Cross sectional differences in mortality rates in middle age are largely explained by levels of mortality in early adulthood which provide a baseline for the subsequent rises in log mortality with age. Differences in cause specific mortality rates are seen to be part of a general pattern of earlier death from all causes in Glasgow, which is apparent from at least early adulthood. The pattern is robust and is not affected in a major way by denominator bias due to migration or boundary change.

The general pattern of improving health is similar to that observed in other populations, such as the United States, where the decline in cor-

Table V Ratio of age group specific all cause mortality rates for Glasgow compared to Edinburgh, estimated in 1979-83, and predicted for 1989-93

\begin{tabular}{|c|c|c|c|c|}
\hline \multirow{2}{*}{$\begin{array}{l}\text { Age group } \\
\text { (years) }\end{array}$} & \multicolumn{2}{|l|}{ Men } & \multicolumn{2}{|l|}{ Women } \\
\hline & $1979-83$ & 1989-93 & $1979-83$ & $1989-93$ \\
\hline $\begin{array}{l}25-34 \\
35-44 \\
45-54 \\
55-64 \\
65-74\end{array}$ & $\begin{array}{l}1.40 \\
1.56 \\
1.54 \\
1.38 \\
1.17\end{array}$ & $\begin{array}{l}\star \\
1.82 \\
1.60 \\
1.57 \\
1.29\end{array}$ & $\begin{array}{l}1.37 \\
1.53 \\
1.42 \\
1.29 \\
1.21\end{array}$ & $\begin{array}{l}\text { ^ } \\
1.37 \\
1.53 \\
1.42 \\
1.28\end{array}$ \\
\hline
\end{tabular}

${ }^{2}$ Derived from parameters in the log-linear model

^Cannot be predicted from statistical model

onary mortality rates from the mid 1960s was part of a decline in all cause mortality rates, ${ }^{20}$ irrespective of age, gender, and race, ${ }^{21}$ and was predicted 10 years earlier. ${ }^{15}$ The origin in early life of poor health in middle age was also noted in 1936 by Kermack and colleagues, who observed that each generation carries the same relative mortality from the age of five years through adult live and even into old age. ${ }^{16}$ These observations have obvious although perhaps not widely recognised implications for the interpretation of mortality trends.

Although our study is concerned primarily with the trend of increasing mortality rates from young adulthood, differences in mortality between Glasgow and Edinburgh have been evident from birth for each cohort in the study (table VII). There is a growing number of studies reporting similar findings ${ }^{24}$ and a controversy concerning their aetiological significance. ${ }^{25}$ Although our data do not permit detailed discussion of this issue, they suggest that the links between health in early life and middle age operate on a larger scale than has been suggested by studies of specific diseases. ${ }^{26-29}$

PREDICTION OF MORTALITY RATES

Our predicted mortality rates for 1989-93 lack precision but suggest that while mortality rates in 
Table VI Estimated percentage net out-migration from Glasgow and Edinburgh, in 10 year age groups between census years during the period 1921-81.

\begin{tabular}{|c|c|c|c|c|c|}
\hline \multirow[b]{2}{*}{ Population } & \multirow[b]{2}{*}{ Period } & \multicolumn{3}{|c|}{ Age at beginning of period (years) } & \multirow[b]{2}{*}{$\begin{array}{l}55-64 \\
(\%)\end{array}$} \\
\hline & & $\begin{array}{l}25-34 \\
(\%)\end{array}$ & $\begin{array}{l}35-44 \\
(\%)\end{array}$ & $\begin{array}{c}45-54 \\
(\%)\end{array}$ & \\
\hline Glasgow men & $\begin{array}{l}1921-31 \\
1931-51 \\
1951-61 \\
1961-71 \\
1971-81\end{array}$ & $\begin{array}{r}6 \cdot 7 \\
3 \cdot 2 \\
13 \cdot 8 \\
28 \cdot 4 \\
29 \cdot 0\end{array}$ & $\begin{array}{r}2.1 \\
1.7 \\
6.9 \\
14.5 \\
12.5\end{array}$ & $\begin{array}{r}5 \cdot 1 \\
3.8 \\
3 \cdot 1 \\
9 \cdot 6 \\
10 \cdot 8\end{array}$ & \begin{tabular}{r}
\multicolumn{4}{c}{$4 \cdot 2$} \\
$\star$ \\
$5 \cdot 4$ \\
$9 \cdot 6$ \\
$11 \cdot 9$
\end{tabular} \\
\hline Glasgow women & $\begin{array}{l}1921-31 \\
1931-51 \\
1951-61 \\
1961-71 \\
1971-81\end{array}$ & $\begin{array}{r}7 \cdot 1 \\
8 \cdot 4 \\
14 \cdot 0 \\
25 \cdot 0 \\
26 \cdot 2\end{array}$ & $\begin{array}{r}3.6 \\
5.6 \\
7.6 \\
14.0 \\
13.3\end{array}$ & $\begin{array}{r}4 \cdot 6 \\
4 \cdot 2 \\
6 \cdot 3 \\
11 \cdot 4 \\
13 \cdot 1\end{array}$ & $\begin{array}{c}-2 \cdot 9 \\
\star \\
5 \cdot 1 \\
10 \cdot 0 \\
12 \cdot 8\end{array}$ \\
\hline Edinburgh men & $\begin{array}{l}1921-31 \\
1931-51 \\
1951-61 \\
1961-71 \\
1971-81\end{array}$ & $\begin{array}{r}5.6 \\
-6.2 \\
6.7 \\
14.0 \\
12.0\end{array}$ & $\begin{array}{r}1.7 \\
-7.5 \\
1.6 \\
3.8 \\
2.6\end{array}$ & $\begin{array}{r}6 \cdot 1 \\
-4 \cdot 8 \\
-0 \cdot 1 \\
2 \cdot 1 \\
4 \cdot 1\end{array}$ & $\begin{array}{l}13 \cdot 1 \\
{ }^{\star} \\
0 \cdot 6 \\
2 \cdot 7 \\
8 \cdot 3\end{array}$ \\
\hline Edinburgh women & $\begin{array}{l}1921-31 \\
1931-51 \\
1951-61 \\
1961-71 \\
1971-81\end{array}$ & $\begin{array}{r}7.9 \\
-1.6 \\
6.6 \\
10 \cdot 2 \\
10.2\end{array}$ & $\begin{array}{r}3.8 \\
-5.9 \\
1.3 \\
3.2 \\
3.9\end{array}$ & $\begin{array}{r}5.5 \\
-8.9 \\
0.6 \\
2.6 \\
6.9\end{array}$ & $\begin{array}{l}4.6 \\
\star^{4} \\
0.8 \\
1 \cdot 8 \\
8 \cdot 3\end{array}$ \\
\hline
\end{tabular}

*Cannot be estimated

Edinburgh may fall, rates in men and in older women in Glasgow are likely to remain constant. The prediction is consistent with the observation that health improves more quickly in populations which are already healthy. ${ }^{30} 31$

It is probable that mortality during 1989-1993 will be determined not only by underlying historical trends, but also by shorter term changes in mortality rates for specific diseases. For

Table VII Comparative data for Glasgow and Edinburgh

\begin{tabular}{|c|c|c|c|c|c|c|}
\hline \multirow{2}{*}{$\begin{array}{l}\text { Risk factor } \\
\text { levels } \text { lat }_{40-59} \\
\text { years }\end{array}$} & \multicolumn{2}{|c|}{$\begin{array}{l}\text { Glasgow } \\
\text { North } \\
\end{array}$} & \multicolumn{2}{|c|}{$\begin{array}{l}\text { Glasgow } \\
\text { South }\end{array}$} & \multicolumn{2}{|c|}{ Edinburgh } \\
\hline & $M$ & $F$ & $M$ & $F$ & $M$ & $F$ \\
\hline \multirow[t]{2}{*}{$\begin{array}{l}\text { Regular smokers \% } \\
\text { Systolic blood pressure mm } \mathrm{Hg} \\
\text { Cholesterol mmol/litre } \\
\text { Fibrinogen } \mathrm{g} / \text { litre } \\
\text { BMI kg/m } \\
\text { Vigorous exercise at home \% } \\
\text { Alcohol units/week } \\
\text { Not eating green vegetables } \% \\
\text { Not eating fruit \% }\end{array}$} & $\begin{array}{c}52 \\
137 \\
6 \cdot 3 \\
2 \cdot 34 \\
25 \cdot 7 \\
15 \\
17 \\
20 \\
30\end{array}$ & $\begin{array}{c}51 \\
134 \\
6 \cdot 5 \\
2 \cdot 42 \\
26 \cdot 2 \\
15 \\
2 \\
12 \\
16\end{array}$ & $\begin{array}{c}51 \\
136 \\
6 \cdot 3 \\
2 \cdot 20 \\
25 \cdot 3 \\
12 \\
14 \\
20 \\
27\end{array}$ & $\begin{array}{c}45 \\
132 \\
6 \cdot 3 \\
2 \cdot 28 \\
26 \cdot 1 \\
18 \\
2 \\
11 \\
16\end{array}$ & $\begin{array}{c}35 \\
133 \\
6 \cdot 4 \\
2 \cdot 38 \\
25 \cdot 5 \\
13 \\
14 \\
6 \\
20\end{array}$ & $\begin{array}{c}33 \\
129 \\
6 \cdot 7 \\
2 \cdot 45 \\
24 \cdot 9 \\
8 \\
4 \\
5 \\
7\end{array}$ \\
\hline & \multicolumn{4}{|c|}{ Glasgow } & \multicolumn{2}{|c|}{ Edinburgh } \\
\hline $\begin{array}{l}1981 \text { Census data } 4041: \\
\% \text { Social class I and II } \\
\% \text { Social class IV and V } \\
\% \text { Owner occupiers } \\
\% \text { With no car } \\
\% \text { Male unemployment } \\
\% \text { Overcrowding ( }>1.0 \text { persons per room) }\end{array}$ & $\begin{array}{l}17 \cdot 6 \\
31 \cdot 7 \\
24 \cdot 9 \\
70 \cdot 6 \\
21 \cdot 6 \\
19 \cdot 9\end{array}$ & & & & $\begin{array}{r}36 \cdot 0 \\
19 \cdot 3 \\
57 \cdot 2 \\
53 \cdot 6 \\
9 \cdot 7 \\
10 \cdot 6\end{array}$ & \\
\hline $\begin{array}{l}\text { Infant mortality rates-deaths } \\
\text { per } 1000 \text { live births } 22 \text { : } \\
1869-73 \\
1889-93 \\
1909-13 \\
1929-33 \\
1949-53 \\
1969-73 \\
1979-83\end{array}$ & $\begin{array}{r}171 \\
149 \\
129 \\
104 \\
43 \\
24 \\
12\end{array}$ & & & & $\begin{array}{r}151 \\
140 \\
108 \\
74 \\
28 \\
19 \\
13\end{array}$ & \\
\hline $\begin{array}{l}\text { Heights of schoolchildren } 2223 \text { : } \\
\text { age } 13 \text { years, height in inches) } \\
1946-47 \\
1956-57 \\
1966-67\end{array}$ & $\begin{array}{l}\text { Boys } \\
58 \cdot 2 \\
59 \cdot 5 \\
60 \cdot 0\end{array}$ & $\begin{array}{l}\text { Girls } \\
59 \cdot 0 \\
59 \cdot 9 \\
60 \cdot 1\end{array}$ & & & $\begin{array}{l}\text { Boys } \\
58 \cdot 7 \\
60 \cdot 0 \\
60 \cdot 9\end{array}$ & $\begin{array}{l}\text { Girls } \\
59 \cdot 5 \\
60 \cdot 3 \\
61 \cdot 0\end{array}$ \\
\hline $\begin{array}{l}\text { Overcrowding } \\
\text { (persons per } 100 \text { rooms }^{51} \text { ): } \\
1871 \\
1891 \\
1911 \\
1931 \\
1951\end{array}$ & $\begin{array}{l}210 \\
189 \\
185 \\
154 \\
127\end{array}$ & & & & $\begin{array}{r}134 \\
123 \\
120 \\
111 \\
93\end{array}$ & \\
\hline $\begin{array}{l}\text { Winter air pollution } \\
\text { (mean smoke concentration } \\
\text { at city centre cites }{ }^{52} \text { ): } \\
1962-63\end{array}$ & & & & & & \\
\hline $\begin{array}{l}1962-63 \\
1972-73\end{array}$ & $\begin{array}{l}\text { Smoke } \\
\mathrm{SO}_{2} \\
\mathrm{Smoke} \\
\mathrm{SO}_{2}\end{array}$ & $\begin{array}{l}399 \\
235 \\
141 \\
131\end{array}$ & $\begin{array}{r}8 \text { sites } \\
15 \text { sites }\end{array}$ & & $\begin{array}{r}193 \\
116 \\
79 \\
77\end{array}$ & $\begin{array}{l}7 \text { sites } \\
8 \text { sites }\end{array}$ \\
\hline
\end{tabular}

example, the general downward trend in mortality rates in the United States incorporated trends of increasing mortality rates from accidents, suicides, homicides, cirrhosis, and lung cancer. ${ }^{21}$ In Glasgow, the recent increase in mortality rates in women aged 45-54 years (fig 1 ) is explained by increasing mortality rates from lung cancer. Obviously, environmental and behavioural factors can be lethal at any age but it appears to be only when these factors affect large numbers of people that the underlying pattern of mortality is disturbed. This is the challenge facing current policies for health promotion.

EXPLANATION OF THE TRENDS

In addition to providing an empirical basis for short term predictions, ${ }^{17}$ the regularity of the pattern underlying differences in mortality between the cities provides a challenge to explain the phenomenon in terms sufficiently broad and plausible to encompass other comparative data.

Simple explanations based on climate and geography (eg, water hardness) seem unlikely, since standardised all cause mortality rates in the suburbs of Eastwood, and Bearsden and Milngavie, which are adjacent to Glasgow, are lower than rates in Edinburgh by $14 \%$ and $17 \%$ respectively. ${ }^{4}$

\section{RISK FACTORS}

Comparison of risk factor levels in 1984-1986 in people aged $40-59$ years ${ }^{32}$ showed that men in Glasgow had slightly higher mean systolic pressure levels and alcohol intakes and slightly lower blood cholesterol and fibrinogen than men in Edinburgh (table VII). Body mass index and vigorous exercise in leisure time were similar. Glasgow women aged 40-59 years took more exercise in leisure time, had slightly higher mean systolic blood pressure levels and body mass indices, but lower blood cholesterol and fibrinogen, and lower mean alcohol intake. The prevalence of regular cigarette smoking was about $50 \%$ higher in Glasgow in both men and women. Glaswegians also consumed less fruit and vegetables.

The differences in smoking and diet between the cities, and the absolute levels of risk factors in both cities, give support to health promotion measures to prevent deaths from coronary heart disease, stroke, and lung cancer. ${ }^{33}$ However, it is unlikely that risk factors explain all of the differences in these diseases ${ }^{34-36}$ New risk factors could explain more of the differences, but with the possible exception of diet, it is difficult to see how risk factors can explain the substantial excess in Glasgow of deaths from other causes at all ages, and the deep rooted nature of observed inequality in health.

SOCIOECONOMIC FACTORS

At the start of the 19th century, Edinburgh and Glasgow had populations of similar size. Although accurate infant mortality data are not available for that period, it is known that infant mortality rates in Glasgow in 1821 were lower than rates reported 20 years later in Edinburgh. ${ }^{37}$ Throughout the second half of the century, there was a flood of population into the west of Scotland from Ireland and the Scottish Highlands, which 
provided the labour force for Glasgow's famous industries of shipbuilding and engineering. Industrial progress was bought with low wages, and poor housing for workers and their families. ${ }^{38}$ By the mid-20th century, heavy industry and slum housing in the inner city had been replaced by endemic unemployment and peripheral housing schemes. In 1973, the document "Born to fail?" illustrated dramatically the extent of multiple deprivation in the west of Scotland. Market forces and public policy had created greater geographical inequalities in the area than in any other conurbation in the UK. ${ }^{39}$

Edinburgh developed differently, becoming a financial, legal, and administrative centre, with relatively little involvement in heavy industry. The different patterns of development are reflected today in the socioeconomic profiles of the cities, with substantially greater proportions of professional people and of owner-occupiers in Edinburgh, and higher proportions of people in Glasgow who are unemployed, live in overcrowded accommodation, and lack a car (table VII).

When the risk factor data mentioned previously are standardised by housing tenure, the differences between Edinburgh and north Glasgow virtually disappear, with the exception of a small excess of smoking in Glasgow. ${ }^{42}$ The main difference between the two populations lies not in their risk profiles, but in general indicators of socioeconomic status. It has been reported that such indicators explain $73 \%$ of the geographical variation in mortality from coronary heart disease in Scotland. ${ }^{43}$

Each city has a similar range of economic circumstances, but the balance of affluence and poverty within each city is markedly different. It seems unlikely that there is anything unique about poor health in Glasgow or good health in Edinburgh. What is unusual, however, is the opportunity to view inequality in health from a historical perspective. Contrasts of this magnitude are usually confined to small areas, for which longitudinal data are not available.

Reviewing variation in mortality in England and Wales, West concluded that the explanation of regional differences was more consistent with an increased tendency to premature death from all causes than with differences in mortality from specific diseases. ${ }^{44-46}$ Our data show that a pattern of earlier death from all causes also contributes to differences in disease specific mortality rates between Glasgow and Edinburgh.

\section{SUSCEPTIBILITY TO DISEASE RISKS}

If populations vary in their tendency to premature death from all causes, it seem likely that differences in mortality between populations are due not only to differences in risk, but also to differences in susceptibility to risk. ${ }^{15} 3046$ This conclusion could help to explain the observation that for a given cigarette consumption the incidence of lung cancer in the west of Scotland is twice as high as in the United States. ${ }^{47}$ The coronary mortality rate for a given cholesterol level is also more than half as high again in the west of Scotland as in the Whitehall study of civil servants (Hole DJ, Lever AF, personal communication).
Data are not available to answer the question of whether differences in health between the people of Glasgow and Edinburgh can be explained on the basis of genetic susceptibility to disease risks. The influx of Irish and Highland stock to the Glasgow population can still be seen by comparing the proportions of column inches in the Glasgow and Edinburgh (Lothian) telephone directories which are taken up by surnames beginning "Mc" or "Mac" $-13 \%$ in Glasgow, $8 \%$ in Lothian. However, it is not clear how genetic factors could predispose to an excess of so many diseases. Historically, infant mortality rates have been substantially lower in Ireland and in the Highlands than in Glasgow. ${ }^{37}$

An alternative explanation is that socioeconomic factors, in addition to their association with risk factor levels, ${ }^{48-50}$ may determine susceptibility to risk. The biological basis of susceptibility is not known, but the combination of a poor start in life, inadequate nutrition, short stature, overcrowding, air pollution, and cigarette smoking (table VII) provides a plausible explanation, possibly mediated through respiratory impairment, 5355 for the vulnerability to poor health of recent generations of Glaswegians.

\section{CONCLUSIONS}

Cross sectional comparisons of disease specific mortality rates in Glasgow and Edinburgh show substantial inequality. Associated differences in smoking and in the consumption of fruit and vegetables give support to policies for health promotion which emphasise individual behavioural change. However, this is a partial view of the inequality in health. The cross sectional differences between the cities are part of a pattern of earlier death from all causes in Glasgow which has been apparent in successive generations from at least early adulthood. Mortality rates have improved in both cities, but are improving more quickly in Edinburgh. In consequence, national health targets will be more difficult to achieve in Glasgow, than in Edinburgh.

Although unidentified local factors may explain part of the contrast in health between Glasgow and Edinburgh, it is unlikely that the underlying historical pattern is unique to the central belt of Scotland. Rather, the pattern may be typical of inequalities in health in many settings, including those observed within Edinburgh and Glasgow.

The practical implication is that campaigns to influence public behaviour in adult life should be complemented by longer term strategies, targetted at the young, to reduce their susceptibility to risk. Major components of the complementary strategy should be measures to combat child poverty and poor housing. ${ }^{56}$

We thank Charles Florey, John Fox, Sally McIntyre, and Chris Robertson who made helpful comments on an earlier draft of this paper, Carol Nichol for setting up the database, and Lindsay Macaulay for producing the figures. The views expressed are ours alone.

1 Scottish Office Home and Health Department. Health Education in Scotland-a national policy statement. Edinburgh: HMSO, 1991

2 Department of Health. The Health of the Nation: A consultative document for health in England. London: HMSO, 1991

3 Tunstall-Pedoe $\mathrm{H}$. The health of the nation: responses. Coronary heart disease. $B M \mathcal{F}$ 1991; 303: 701-4. 
4 Registrar General of Scotland. Annual reports. Edinburgh: HMSO.

5 Registrar General of Scotland. Census Reports. Edinburgh: HMSO.

6 Clayton D, Schifflers E. Models for temporal variation in cancer rates 1: Age-period and age-cohort models. Stat Med 1987; 6: 449-67.

7 McCullough P, Nelder J. Generalised linear models. London: Chapman and Hall, 1983.

8 Boyle P, Robertson C. Statistical modelling of lung cancer and laryngeal cancer incidence in Scotland, 1960-1979. Am f Epidemiol 1987; 125: 731-44.

9 Breslow NE, Lubin JH, Marek P, Langholz B. Multiplicative models and cohort analysis. $7 \mathrm{Am}$ Stat Assoc 1983; 78: $1-12$.

10 Payne CD. The GLIM System. Release 3.77. Oxford: NAG, 1987.

11 Little RJA, Pullmun TW. The general linear model and direct standardisation. A comparison. Sociol Methods Res 1979; 7: 475-501.

12 Fox AJ, Goldblatt PO, Adelstein AM. Selection and mortality differentials. F Epidemiol Community Health 1982; 36: 69-79.

13 Editorial. Models of mortality. Lancet 1991; 337: 275.

14 Reading VM, Weale RA. A new analysis of United Nations mortality statistics. Mech Ageing Dev 1991; 57: 25-48.

15 Jones HB. A special consideration of the ageing process, disease and life expectancy. Adv Biol Med Physics 1956; 4 281-333.

16 Kermack WO, McKendrick AG, McKinley PL. Death rates in Great Britain and Sweden. Some general regularities and their significance. Lancet 1934; i: 698-703.

17 Greenwood $M$. English death rates, past, present and future. f R Stat Soc 1936; 99: 674-707.

18 Barclay RS, Kermack WO, McKendrick AG. Comparison of the specific mortality rates in town and country districts of the specific mortality rates in town and country dist

19 Davey Smith G, Bartley M, Blane D. The Black Report on socioeconomic inequalities in health 10 years on. $B M \mathcal{F}$ 1990; 301: 373-7.

20 Rosenberg HM, Klebba AJ. Trends in cardiovascular mortality with a focus on ischaemic heart disease: United States 1950-76. United States Department of Health, Education and Welfare. Proceedings of the conference on the decline in coronary heart disease mortality Bethesda MD, 1979. (NIH Publ No 79-1610.)

21 Ueshima H, Cooper R, Stamler J, et al. Age specific mortality trends in the U.S.A from 1960 to 1980: divergent age-sex color patterns. $\mathcal{F}$ Chron $D i s$ 1984; 37: 425-39.

22 Medical Officer of Health of Glasgow. Annual reports. Glasgow: Corporation of the City of Glasgow.

23 Medical Officer of Health of Edinburgh. Annual reports. Edinburgh: Corporation of the City of Edinburgh.

24 Barker DJP. The fetal and infant origins of adult disease (editorial). BMF 1990; 301: 1111.

25 Ben-Shlomo Y, Davey Smith G. Deprivation in infancy or in adult life: which is more important for mortality risk? Lancet 1991; 337: 530-4.

26 Barker DJP, Osmond C. Childhood respiratory infection and adult chronic bronchitis in England and Wales $B M \mathcal{J}$ 1986; 293: 1271-5.

27 Barker DJP, Winter PD, Osmond C, et al. Weight in infancy and death from ischaemic heart disease, Lancet 1989; ii: $577-80$

28 Barrker DJP, Bull AR, Osmond CR, et al. Fetal and placental size and risk of hypertension in adult life. $B M \mathcal{F}$ 1990; 301: 259-62.

29 Barker DJP, Godfrey KM, Fall C, et al. Relation of birthweight and childhood respiratory infection to adult lung function and death from chronic obstructive airways disease. $B M F$ 1991; 303: 671-5.

30 Marmot MG, McDowall ME. Mortality decline and widening social inequalities. Lancet 1986 ; ii: $274-6$.

31 Joseph KS. The Mathew effect in health development. $B M F$ 1989; 298: 1497-8.
32 Tunstall-Pedoe H, Smith WCS, Crombie IK, Tavendale R. Coronary risk factor and lifestyle variation across Scotland: results from the Scottish Heart Health Study. Scot Med $\mathcal{f}$ 1989; 34: 556-60.

33 Pocock SJ, Shaper AG, Cok DG, Phillips AN, Walker M. Social class differences in ischaemic heart disease in British men. Lancet 1987; ii: 197-200.

34 Haan M, Kaplan GA, Camacho T. Poverty and health. Prospective evidence from the Alameda County study. Am Prospective evidence from the Alat

35 Marmot MG, Shipley MJ, Rose G. Inequalities in deathspecific explanations of a general pattern? Lancet 1984; specific $1003-6$.

36 Davey Smith G, Shipley MJ, Rose G. Magnitude and causes of socioeconomic differentials in mortality: further evidence from the Whitehall Study. $\mathcal{F}$ Epidemiol Community Health 1990; 44: 265-70.

37 Williams R. Medical, economic, and population factors in areas of high mortality in Britain: the case of Glasgow. Glasgow: MRC Medical Sociology Unit (Working paper No. 35).

38 Smout TC. A century of the Scottish people. London: Collins, 1986

39 Wedge P, Prosser H. Born to fail? London: National Children's Bureau, 1973.

40 Registrar General of Scotland. Census report 1981. Report for Lothian, vol 2, table 49. Edinburgh: HMSO.

41 Registrar General of Scotland. Census report 1981. Report for Strathclyde, vol 2, table 49. Edinburgh: HMSO.

42 Smith WCS, Shewry MC, Tunstall-Pedoe HD, Crombie IK, Tavendale R. Coronary heart disease in Edinburgh and North Glasgow. A tale of two cities. F Clin Epidemiol 1990 43: $637-43$.

43 Crombie IK, Kenicer MB, Smith WCS, Tunstall-Pedoe HD. Unemployment, socio-environmental factors, and coronary heart disease in Scotland $B r$ Heart $\mathcal{F} 1989 ; 61$ : 172-7.

44 West RR. Geographical variation in mortality from ischaemic heart disease in England and Wales. $\mathrm{Br} \mathcal{F}$ Prev Soc Med 1977; 31: 245-50.

45 West RR. High death rates: more deaths or earlier deaths. $f$ $R$ Coll Physicians Lond 1987; 21: 73-6.

46 Cassel J. The contribution of the social environment to host resistance. Am $\mathcal{F}$ Epidemiol 1976; 104: 107-23.

47 Gillis CR, Hole DJ, Hawthorne VM. Cigarette smoking and male lung cancer incidence in an area of very high incidence II Report of a general population cohort study in the West of Scotland. $\mathcal{F}$ Epidemiol Community Health 1988; 42: 44-8.

48 Shaper Ag, Pocock SJ, Walker M, Cohen NM, Wale CJ, Thomson AG. British Regional Heart Study: cardiovascular risk factors in middle-aged men in 24 towns. BMF 1981; 283: 179-86.

49 Cummins RO, Shaper AG, Walker M, Wale CJ. Smoking and drinking by middle-aged men: effects of social class and town of residence. $B M \mathcal{F} 1981 ; 283$ : 1497-502.

50 Thelle DS, Shaper AG, Whitehead TP, Bullock DG, Ashby $\mathrm{D}$, Patel ILA. Blood lipids in middle-aged British men. $\mathrm{Br}$ Heart $\mathcal{F}$ 1983; 49: 205-13.

51 Registrar General of Scotland. Census 1951, vol 1, part 2 , table 20. Edinburgh: HMSO

52 Warren Spring Laboratory. National survey of air pollution 1961-71, vol 5. London: HMSO, 1976.

53 Walker M, Shaper AG, Phillips AN, Cook DG. Short stature, lung function and risk of a heart attack. Int $\mathcal{f}$ Epidemiol 1989; 18: 602-6.

54 Ebi-Kryston KL, Hawthorne VM, Rose G, et al. Breathlessness, chronic bronchitis and reduced pulmonary function as predictors of cardiovascular disease mortality among men in England, Scotland and the United States. Int 7 Epidemiol 1989; 18: 84-8.

55 Kuller LH, Ockenen JK, Townsend M, Browner W, Meilahn E, Wentworth DN. The epidemiology of pulmonary function and COPD mortality in the Multiple Risk Factor Intervention Trial. Am Rev Respir Dis 1989; 140: S76-81.

56 Morris JN. Inequalities in health: ten years and little further on. Lancet 1990; ii: 491-3. 